\title{
Miły sercu przewodnik po Sarmacji
}

\section{Wojciech Kaliszews Ki}

(Instytut Badań Literackich PAN, Warszawa)

Jacek Kowalski, Sarmacja. Obalanie mitón. Podręcznik bojowy, WydawNictwo ZoNa Zero, WARsZawa 2016, ss. 398

Miłość do Sarmacji nie powinna, a nawet nie może wykluczyć próby chłodnego, opartego na badaniach źródłowych i tym samym mniej emocjonalnego stosunku do tej wielkiej i wciąż żywej opowieści o naszej genealogii narodowej. Jednak zbyt gwałtowne obniżenie temperatury badawczej może z kolei grozić zamrożeniem tego, co w sarmackiej historii żywe i autentyczne. Trzeba bowiem wyraźnie podkreślić, że Sarmacja nie jest pojęciem martwym, pozbawionym dzisiaj treści znaczących i ważnych. Przeciwnie - Sarmacja żyje wciąż w naszych formach kulturowych, ma swój niemały udział w kształtowaniu współczesnej mentalności i tym samym w tworzeniu zachowań oraz relacji wewnątrzspołecznych. Jest Sarmacja także - to prawda, że nie zawsze jasno rozpoznawanym - punktem na mapie geopolitycznych struktur Europy Zachodniej. I jest bodaj najważniejszą z tych struktur, które pozwalały (i wciąż pozwalają) łączyć to, co wschodnie, i to, co zachodnie, orientalno-grecko-bizantyńskie i łacińskie, jeśli nie w spójną całość, to na pewno w jedność przeciwieństw. Te różnice i odmienności, a zarazem podobieństwa były doskonale znane i definiowane w dawnej refleksji historiograficznej. Przypomnijmy, że w I5I7 roku ukazało się pierwsze wydanie (wznawianego później wielokrotnie) traktatu łacińskiego Macieja Miechowity Tractatus de duabus Sarmatiis Asiana et Europiana et de contentis in eis, który te różnice i podobieństwa zestawiał i przedstawiał. Traktat ten stanowi zresztą nie tylko źródło służące poznaniu Sarmacji, ale jest także arcyważnym i ciekawym świadectwem staropolskiej recepcji wszystkich treści, które z sarmackością się wówczas łączyły i kojarzyły.

Zależności między polskością a sarmackością rysowały się na wielu poziomach. Jednym z nich był niezwykle istotny poziom związków osobowościowych, genealogicznych, nieomal rodzinnych. Kilkadziesiąt lat po Miechowicie, w I597 roku, 
w Kronice polskiej Marcina Bielskiego, nowo przez Joachima Bielskiego, syna jego, wydanej znaleźć można takie oto zdanie: „Wszakże skądbykolwiek to imię było, tedy to jawna i jasna rzecz jest, żechmy my są Sarmatae własni; i przeto cokolwiek o Sarmatach pisano, to się słusznie ma rozumieć o przodkach naszych". Sarmacja była (i jest) zatem „w nas”, była (i jest nadal) cząstką naszej własnej rodowo-domowej tradycji. Polacy wrośnięci w Sarmację nie tyle byli jej spadkobiercami, co - czując ją wewnętrznie - byli wciąż jej dziećmi, byli z nią silnie zrośnięci, w niej widzieli swą przyszłość.

Sarmacja, wyraźnie obecna w staropolskiej historiografii, łączona w różnych kontekstach $\mathrm{z}$ rodowodem przede wszystkim szlachty, stała się $\mathrm{w}$ drugiej połowie XVIII wieku celem ostrej krytyki, satyrycznych ataków i kpin. Można by tutaj przywoływać antysarmackie artykuły z „Monitora” i zdecydowanie nieprzychylne sarmackim tęsknotom tytuły różnych utworów literackich. Sarmacja po prostu nie odpowiadała wizji państwa nowoczesnego, odwołującego się do zupełnie innej sfery wartości. Doszło wówczas do konfrontacji dwóch systemów mentalnych, do swoistego, bo lokalnego, polskiego zderzenia „starożytników z nowożytnikami”. Pisał o tych starciach i sporach w sposób wyczerpujący Janusz Maciejewski w książce Dylematy wolności. Zmierzch sarmatyzmu i początki Oświecenia w Polsce, analizując tło polityczne, kulturowe i historyczne „kryzysu formacji sarmackiej”. Maciejewski dostrzegał przyczyny „zmierzchu sarmatyzmu” - zauważmy, że w perspektywie historycznoliterackiej mówi się o prądzie sarmackim jako o zwartej ideologii, a więc używa się terminu „sarmatyzm” - w konieczności szukania wyjścia „z dylematów, w jakich znaleźli się Polacy”; kryzys polityczny czasów stanisławowskich domagał się bowiem „zbudowania nowego systemu wartości”. Liczono na Oświecenie. Ale to, co było planem i projektem, nie do końca odpowiadało rzeczywistości. Sarmacja przeżyła nie tylko tamten katastrofalny kryzys, ale przetrwała jeszcze wiele innych kryzysów, stając się swoistym zapleczem tradycji, wartości i źródłem pocieszenia dla Polaków na przestrzeni wielu następnych dziesięcioleci. Taki właśnie wniosek płynie z lektury książki Jacka Kowalskiego zatytułowanej Sarmacja. Obalanie mitów. Podręcznik bojowy. Jest to publikacja pod wieloma względami ciekawa, warta lektury i niejako obowiązkowa dla każdego, kto zajmuje się historią kultury jako żywym i wciąż rozwijającym się organizmem tak zbiorowej, jak i indywidualnej wyobraźni.

Sarmacja... Kowalskiego - historyka sztuki, artysty, pisarza i człowieka, który czas teraźniejszy łączy bezpośrednio z przeszłym - jest szukaniem odpowiedzi na pytanie o istotę Sarmacji. Nie jest to jednak książka stricte naukowa. Zakres tematyczny, styl, sposób ujmowania i wyjaśniania poszczególnych zagadnień oraz

1 J. Maciejewski, Dylematy wolności. Zmierzch sarmatyzmu i początki Oświecenia w Polsce, Warszawa 1994, passim. 
formułowanie wniosków wykraczają poza ramy pracy tylko i wyłącznie badawczej, obiektywnie weryfikującej zebrane fakty. Sarmacja... to obszerny esej, a raczej zbiór esejów poświęconych wielu aspektom sarmackiej tradycji. Do tego autor zaciera $\mathrm{w}$ książce granicę biegnącą pomiędzy badaczem a uczestnikiem badanej rzeczywistości. To uruchamia efekt współuczestniczenia w przedstawianych wydarzeniach. Dodatkowym czynnikiem scalającym te dwa wymiary jest język pracy. Kowalski wprowadza do swojego Podręcznika bojowego tonację gawęd szlacheckich, potrafi archaizować składnię i leksykę. Czytelnik niejako wtapia się podczas lektury w sarmackość, nie przesądzając przy tym o jej niskiej lub wysokiej wartości. Takie „odśrodkowe” widzenie problematyki pozwala zniwelować dystans do badanych faktów. Jest to więc książka osobista, łącząca historię z przedstawieniem wartości wybranych i akceptowanych przez autora.

Jacek Kowalski zajął się - jak podkreślił w tytule - „obalaniem mitów”, czyli "zabobonów” - na temat sarmackości, które tworzyła nieprzychylna jej historiografia. Stąd podtytuł książki: Podręcznik bojowy, jest to bowiem swoista walka o wyprowadzenie sarmackiej tradycji z otchłani, do której zepchnęło ją nie tylko Oświecenie, ale i późniejsze, w tym także powojenne - tak zwane racjonalne i postępowe - myślenie o historii, ponieważ na tym gruncie rozwinęły się mylne sądy na temat sarmackości, które autor nazywa - przewrotnie - zabobonami i które krok po kroku demaskuje. Sarmacjq... autor chce zwrócić naszą uwagę właśnie na Sarmację, na dane i zadane nam przez historię dziedzictwo.

Bitwa o Sarmację rozgrywa się na czterech głównych polach tematycznych. Są to części książki, grupujące - ponumerowane - owe „zabobony”. Pierwsza z nich, wprowadzająca czytelnika w problematykę, lączy się z kwestią oczyszczenia sarmackości z przekłamań i fałszywych oskarżeń. Autor podkreśla jednocześnie znaczenie sarmackości jako zwornika kultury w dawnej Polsce. Tutaj także zapisana została bardzo ważna dla wymowy tekstu teza o żywotności sarmackości w polskiej kulturze współczesnej. Kowalski powiada, że sarmackość „współbrzmi” z tym, co rozgrywa się na naszych oczach, że żyje „życiem ukrytym” i że jest „zarazem silnie obecna”, ale w pewnych obszarach bywa „kompletnie zapomniana”. Odsłania te sfery współczesnego życia, które wciąż jeszcze odwołują się do sarmackiego ducha, śledząc nie tylko ślady literackie, ale i te, które odcisnęly się w sferze politycznej.

Część druga wkracza w dziedzinę „zabobonów” uformowanych w czasach dawnych. To odczytanie tekstów łączonych później z sarmackością jako z treścią i przesłaniem niejasnym, ciemnym i wręcz niemądrym. Kowalski podaje przykłady najrozmaitszych kompendiów i dykcjonarzy czasów sarmackich z Nowymi Atenami Chmielowskiego na czele. Autor Sarmacji... w tej wielkiej i rozgałęzionej literaturze ceni sobie wartości stylu, jędrność i dosadność języka, trafność określeń i siłę fraz. W tej części można znaleźć również coś, co można by nazwać katalogiem wątków 
sarmackich rozsianych po literaturze wieku XVI, XVII i XVIII. A więc idących od Kochanowskiego, Bielskiego, Kochowskiego po Karpińskiego i innych. To bardzo szeroki przegląd i bogata antologia tematów. Jeśli przyjrzeć im się uważnie, należy stwierdzić, że to one kształtowały naszą zbiorową wyobraźnię i fantazję.

Trzecie pole ma charakter wizerunkowy. To zestawienie portretów, konterfektów, opisów i przedstawień. Kowalski proponuje tutaj coś, co można by nazwać wielkim obserwatorium różnych scen sarmackiego życia - od bitewnych po sejmowe i elekcyjne. Wszystko to razem wzięte składa się na szeroką panoramę wciąż otwartą, wciąż dopełnianą i uzupełnianą przez czasy nam współczesne. Takim punktem odniesienia są na przykład wydarzenia okresu solidarnościowego najnowszej polskiej historii.

Część czwarta i ostatnia to wprowadzenie do wnętrza domu. Stajemy - prowadzeni przez autora - na ganku sarmackiego dworu, który był - potwierdzi to każdy czytelnik Pana Tadeusza - miejscem znaczącym i centralnym. Stąd się wyruszało w świat dalszy czy bliższy i tutaj się wracało. I - tak jak w poprzednich częściach - Jacek Kowalski przytacza opisy i cytuje fragmenty utworów przedstawiających dwory, zabudowania, folwarki i wsie wrastające nie tylko w krajobrazy, stanowiące część pejzażu, ale również będące jakże ważnym elementem myślenia sarmackiego, niezależnego, wyrastającego z poczucia wolności i niezależności. Pojawia się w tej części obraz domu wiejskiego jako miejsca szczególnego, bo stojącego wyraźnie w opozycji do miasta, do przestrzeni zurbanizowanej. Wieś w sarmackim świecie stanowiła przestrzeń wolną i niezależną. Dom wiejski dawał poczucie bezpieczeństwa, otwierał się zarazem na gości i przybyszów. Dom sarmacki był żywym i czułym towarzyszem człowieka.

Historie dworów, siedzib rodzinnych, zaścianków i folwarków przechowują w sobie wiele niezwykłych i często zapomnianych wątków, łączących losy osobiste różnych bohaterów z losami narodu. To wciąż jeszcze niezbadany do końca rozdział polskiej historii.

Sarmacja - tak jak rozumie i przedstawia ją Jacek Kowalski - oznacza wolność w sensie zewnętrznym i wewnętrznym ${ }^{2}$. To wolność ducha. Sarmackość stanowi dla autora jeden $\mathrm{z}$ fundamentów polskiej tożsamości kulturowej i narodowej. Można oczywiście z taką tezą polemizować i warto w tym miejscu przywołać choćby książkę Janusza Tazbira Kultura szlachecka w Polsce. Rozkwit - upadek - relikty, w której sarmackość przedstawiana jest nie tyle jako stan ducha, ile jako system idei oraz form zachowania, a więc jako sarmatyzm. Stąd ślady i echa sarmackości w świecie współczesnym Tazbir traktuje krytycznie, jako relikty, anachronizmy i przeżytki.

2 Na temat sarmatyzmu, jego roli i znaczenia dla współczesnej polskiej kultury zob. K. Koehler, Palus sarmatica, Warszawa 2016. 
Sarmacje... Jacka Kowalskiego nazwać można na pewno przewodnikiem po świecie dalekim, a zarazem bliskim, trochę obcym, ale mimo to swojskim, miłym sercu. Czy jest „podręcznikiem bojowym”? Myślę, że to hiperbola, ale oczyszczenie obrazu kultury sarmackiej musi się dokonać. Powtórzę przy tym raz jeszcze to, co napisałem wyżej: ta książka jest esejem, jest godną zauważenia próbą uchwycenia nieulatującej ulotności, jaką była i wciąż jest sarmackość. 